\title{
Physical Performance Testing
}

National Cancer Institute

\section{Source}

National Cancer Institute. Physical Performance Testing. NCI Thesaurus. Code C150523.

Any of various activities and tests designed to assess an individual's physical fitness. 